JURNAL PARIS LANGKIS

Jurnal Pendidikan Pancasila dan Kewarganegaraan

Vol.1 Nomor 2, Maret 2021

E-ISSN: 2723-7001

https://e-journal.upr.ac.id/index.php/parislangkis

\title{
MENGKAJI NILAI-NILAI KEARIFAN LOKAL PERANG OBOR TERHADAP SEMANGAT NASIONALISME
}

\author{
Alvin Noor Fitrian ${ }^{1}$, Wulan Septiyani ${ }^{2}$ \\ ${ }^{1}$ Program Studi Teknik Industri, Fakultas Teknik Industri, Universitas Pembangunan Nasional \\ Veteran Yogyakarta \\ ${ }^{2}$ Program Studi Akuntansi, Fakultas Ekonomi Bisnis, Universitas Pembangunan Nasional Veteran \\ Yogyakarta \\ email:alvinnoorf@gmail.com ${ }^{1}$, septiyaniwulann@gmail.com²
}

\begin{abstract}
Abstrak:
Manusia dan kebudayaan adalah dua elemen yang tidak dapat dipisahkan.Kebudayaan merupakan kekayaan alam yang tercipta karena adat istiadat turun-temurun yang diciptakan oleh manusia itu sendiri.Perang obor di Desa Tegalsambi, Kabupaten Jepara adalah salah satu contoh budaya yang sudah melekat sejak dahulu.Perang obor merupakan atraksi pertunjukan tradisional sebagai ungkapan rasa syukur kepada Tuhan Yang Maha Kuasa.Perang Obor memiliki nilai-nilai kearifan lokal seperti kebersamaan, gotong royong, toleransi, empati, kesetiakawanan, dan religius.Kebesaran jiwa dalam sebuah bangsa yang majemuk sangat penting bagi keberlangsungan kehidupan bermasyarakat, berbangsa, dan bernegara.Nilai-nilai kearifan lokal dari suatu kebudayaan harus mampu mengukuhkan jati diri sebagai bangsa yang memiliki semangat nasionalisme.Penelitian ini mengkaji nilai-nilai kearifan lokal yang terkandung dalam tradisi perang obor ditinjau dari semangat nasionalisme yang merujuk pada Pancasila sebagai dasar falsafah Bangsa Indonesia.Metode yang digunakan dalam mengkaji nilainilai kearifan lokal perang obor terhadap semangat nasionalisme yaitu analisis kualitatif deskriptif.Analisis dilakukan berdasarkan studi literatur yang mendalam dengan mengedepankan data dan fakta darilapangan. Hasil uraian pada penelitian ini menunjukkan bahwa nilai-nilai kearifan lokal yang terkandung dalam tradisi perang obor sejalan dengan norma kehidupan yang berlandaskan pada butir-butir Pancasila sebagai dasar falsafah bangsa.
\end{abstract}

Kata Kunci:Perang Obor, Nilai Kearifan Lokal, Budaya, Nasionalisme.

Paris Langkis

Vol.1 Nomor 2, Maret 2021 


\begin{abstract}
:
Humans and culture are two inseparable elements. Culture is a natural wealth that is created because of hereditary customs created by humans themselves. The Torch War in Tegalsambi Village, Jepara Regency is one example of a culture that has been inherent for a long time. The Torch War is a traditional performance attraction as an expression of gratitude to God Almighty. The Torch War has local wisdom values such as togetherness, mutual cooperation, tolerance, empathy, solidarity, and religion. The greatness of the soul in a pluralistic nation is very important for the continuity of life in society, nation and state. The values of local wisdom from a culture must be able to strengthen its identity as a nation that has a spirit of nationalism. This research examines the values of local wisdom contained in the torch war tradition in terms of the spirit of nationalism which refers to Pancasila as the basis for the philosophy of the Indonesian nation. The method used in assessing the values of local wisdom of the Torch War against the spirit of nationalism is descriptive qualitative analysis. The analysis was carried out based on an in-depth literature study by prioritizing data and facts from the field. The results of the description in this study indicate that the values of local wisdom contained in the torch war tradition are in line with the norms of life which are based on the points of Pancasila as the basis of the nation's philosophy.
\end{abstract}

Keywords: Torch War, Local Wisdom Values, Culture, Nationalism.

\title{
A. PENDAHULUAN
}

Perang obor menjadi salah satu tradisi tahunan yang sudah dijalankan oleh masyarakat Desa Tegalsambi, Kabupaten Jepara. Perang obor dilaksanakan pertama kali pada abad ke-16 Masehi yang merupakan cerminan dari certa rakyat Kiai Babadan dan Ki Gemblong(Aristanto, 2011). Perang obor ini merupakan puncak kegiatan dari rangkaian upacara sedekah bumi bagi masyarakat setempat.Sedekah bumi ini dilakukan sebagai bentuk ungkapan rasa syukur kepada Tuhan Yang Maha Kuasa atas segala berkat dan kesejahteraan yang diberikan bagi warga Desa Tegalsambi.Perang obor dilaksanakan setahun sekali dalam kalendar Hijriyah, yaitu pada Hari Senin Pahing malam Selasa Pon di bulan Zulkaidah (Apit).Tujuan diadakannya perang obor ini untuk mengusir kejahatan dan menolak bala dari segala macam gangguan dan menghindarkan masyarakat setempat dari sengkolo atau marabahaya.

Meningkatnya konflik antar etnis dan antar agama di Indonesia menyebabkan nasionalisme semakin terpuruk (Supardan, 2013). Globalisasi juga memberikan pengaruh yang cukup signifikan mengenai degradasi kebudayaan dan nasionalisme (Agustin, 2011). Kebudayaan merupakan warisan nenek moyang sebagai manifestasi kehidupan alam semesta.Oleh karena itu, di tengah krisis nasionalisme yang sedang marak, kita sebagai Bangsa Indonesia harus senantiasa melestarikan budaya tradisional.Budaya tradisional bukan menjadi suatu halangan dan pembatas untuk bersatu padu.Keragaman dan Kebhinnekaan Indonesia justru menjadi senjata yang paling ampuh untuk mempertahankan persatuan dan kesatuan bangsa.

Setiap tradisi dan budaya selalu memiliki nilai-nilai kearifan lokal.Nilai kearifan lokal inilah yang membuat masyarakat senantiasa melestarikan budaya tradisonal.Perang obor di Desa Tegalsambi memiliki nilai kearifan lokal seperti kebersamaan, gotong royong, toleransi, empati, kesetiakawanan, dan religius. "Perang" dalam tradisi perang

Paris Langkis

Vol.1 Nomor 2, Maret 2021 
obor bukan dimaknai sebagai suatu ancaman yang dapat memecah belah persatuan dan kesatuan bangsa.Tradisi dan kebudayaan-kebudayaan lokal tersebut justru menjadikan kita lebih memahami makna semangat persatuan dengan menjunjung tinggi keberagaman dalam setiap sendi-sendi kehidupan.Hal yang sama juga pernah diungkapkan (Suryawandan \& Danial, 2016) pada penelitiannya berjudul "Implementasi Semangat Persatuan pada Masyarakat Multikultural melalui Agenda Forum Kerukunan Umat Bergama Kabupaten Malang". Pada penelitian kali ini dilakukan analisis berdasarkan kajian teoritis dan melandaskan uraian pada fakta yang terjadi di lapangan.

\section{B. KAJIAN TEORI}

Kebudayaan adalah manifestasi kehidupan yang meliputi segala perbuatan manusia dan benda yang dipadukan sebagai keseluruhan konsep yang dinamis (Peursen, 1976). (Harsojo, 1988) menyebutkan bahwa aspek pertama dari sistem budaya adalah gagasan yang mencakup nilai-nilai, norma-norma, hukum, dan peraturan yang dianut oleh masyarakat sebagai bagian dari pikiran manusia yang sifatnya abstrak.Nilai-nilai dalam kebudayaan bekerja dalam fungsi ruang dan waktu.Maksudnya, nilai-nilai yang terkandung dalam suatu kebudayaan dapat berubah seiring perkembangan zaman.Perbedaan ini dapat disebabkan berbagai macamfaktor.Salah satu yang paling sering terjadi yaitu masuknya budaya asing dan akulturasi dari budaya itu sendiri.Tingkat kedua dalam sistem budaya adalah norma-norma yang lebih konkrit.Norma-norma tersebut dijadikan sebagai penuntun bagi masyarakat dalam bertingkah laku.Sehingga timbul kepercayaan apabila budaya tersebut ditinggalkan dapat menyebabkan keseimbangan kehidupan terganggu dan menimbulkan bencana.Kondisi seperti ini dalam Masyarakat Jawa disebut kualat.Sedangkan tingkat ketiga dari sistem budaya adalah sistem hukum.Kebudayaan sudah diatur secara jelas dalam suatu masyarakat baik secara tertulis maupun tidak tertulis.

Kearifan lokal menjadi penentu suatu bangsa dalam kebudayaan tradisional yang tidak hanya merujuk pada norma-norma dan nilai-nilai hidup, namun juga berpengaruh terhadap perkembangan teknologi, kesehatan, dan kesenian(Rosdiana \& Saefudin, 2018). Kearifan lokal merupakan warisan yang tangible (dapat dipegang dan dirasakan) dan intangibel (hanya dapat dirasakan)(Sedyawati, 2006). Peran dan fungsi kearifan lokal antara lain untuk melestarikan sumber daya alam, pengembangan sumber daya manusia, pengembangan kebudayaan dan ilmu pengetahuan, sebagai sumber kepercayaan, sarana membangun integrasi komunal, landasan etika dan moral, serta fungsi politik (Sartini, 2004). Kebudayaan memiliki peran dan fungsi yang pokok dan mendasar yang menjadikannya sebagai landasan dalam menyusun tatanan kehidupan bermasyarakat, berbangsa, dan bernegara(Setyowati, 2019).

Berdasarkan sejarahnya, nasionalisme telah menunjukkan perkembangan yang sangat pesat.Berawal pada tahun 1916 saat kongres nasional Centrale Sarekate Islam (CSI) di Bandung, yang selanjutnya berkembang menjadi rasa senasib sepenanggungan, hingga saat ini golobalisasi dan masuknya budaya individualisme ke Indonesia. Nasionalisme Indonesia adalah kekuatan utama yang didorong oleh kebangkitan dan kesadaran nasional yang dikemukakan oleh para intelektual, sehingga berkembang menjadi gerakan massa anti-kolonial melalui partai-partai gerakan nasional (Alfian, 1996).Pernyataan

Paris Langkis

Vol.1 Nomor 2, Maret 2021 
tersebut bukan mempersempit ruang lingkup nasionalisme yang hanya melawan kolonial, namun juga membangun konteks bagaimana nasionalisme dapat diilhami sebagai semangat untuk mempertahankan kedaulatan bangsa dan kearifan nilai budaya nasional.

\section{METODOLOGI PENELITIAN}

Metodologi yang digunakan dalam penelitian ini yaitu analisis kualitatif deskriptif.Analisis dilakukan berdasarkan studi literatur yang mendalam dengan melakukan pendekatan budaya Islam.Studi literatur mengacu pada buku-buku antropologi Keislaman dan kebudayaan, jurnal nasional dan internasional yang relevan dan terpublikasi secara bebas, artikel online, dan referensi lain yang relevan. Ruang lingkup penelitian ini difokuskan menganalisis nilai-nilai kearifan lokal yang terkandung dalam tradisi perang obor.Penggalian data dan fakta pada penelitian ini difokuskan pada pengamatan secara langsung terhadap budaya yang dianut oleh masyarakat setempat.Hasil penelitian dilakukan dengan menganalisis nilai-nilai kearifan lokal dari tradisi perang obor ditinjau dari semangat nasionalisme dan jiwa patriotisme yang tinggi sebagai bangsa Indonesia.Peninjauan yang dilakukan merujuk pada butir-butir kelima sila Pancasila sebagai dasar falsafah Bangsa Indonesia.

\section{HASIL DAN PEMBAHASAN}

Tradisi perang obor di Desa Tegalsambi sudah menjadi suatu kebudayaan yang dilakukan terus-menerus.Konsep perang obor yang dijalankan sudah mengalami beberapa kali perubahan sesuai dengan konsep budaya yang dinamis. Masyakarat juga percaya apabila perang obor tidak dijalankan akan memberikan mudharat bagi warga Desa Tegalsambi. Masyarakat Desa Tegalsambi percaya bahwa perang obor akan menghindarkan masyarakat dari mara bahaya. Hal ini diilhami berdasarkan cerita rakyat dengan tokoh Kiai Babadan dan Ki Gemblong (Ratri, 2010). Abu dan percikan dari bara obor yang jatuh di tanah Tegalsambi dipercaya mampu menangkal segala perilaku buruk, bencana, hingga wabah penyakit. Saat ini, perang obor menjadi daya tarik wisatawan dari beberapa daerah di Jepara dan sekitarnya.Dinas Pariwisata Kabupaen Jepara-pun terlibat secara langsung dalam acara ini sekaligus bertanggung jawab terhadap terselenggaranya upacara tradisional ini.

Obor yang digunakan dalam perang obor terbuat dari pelepah daun kelapa yang diisi daun pisang yang dikeringkan dan diikat pada sebatang bambu serta dibentuk menyerupai obor. Ratusan obor akan diletakkan di beberapa titik lokasi tempat dilaksanakannya ritual perang obor, yaitu disekitar perempatan Desa Tegalsambi. Perang obor dimulai dengan ritual doa bersama yang dilanjutkan dengan penyalaan obor pertama. Obor pertama dinyalakan oleh Bupati Jepara dan Kepala Desa Tegalsambi. Obor-obor lainnya selanjutnya dinyalakan masing-masing dan para peserta perang obor akan memulai "perang" menggunakan senjata obor.

Pelepah daun kelapa menggambarkan kehidupan nyata.Pohon kelapa dikenal sebagai pohon dengan seribu manfaat.Hal ini dikarenakan banyaknya manfaat yang diberikan pohon kelapa mulai dari akar, batang, buah, hingga daunnya.Sehingga, tidak jarang banyak orang menganggap bahwa pohon kelapa sebagai cerminan kehidupan manusia.Salah satu yang masih melekat dengan jelas adalah cerita Maha Patih Gajah

Paris Langkis

Vol.1 Nomor 2, Maret 2021 
Mada dengan Sumpah Amukti Palapa. Masih banyak perdebatan mengenai apa itu Palapa, namun beberapa ilmuan meyakini bahwa Palapa adalah buah kelapa (Munandar, 2010). Hal ini dikarenakan banyaknya manfaat buah kelapa yang dijadikan sebagai penopang bagi kehidupan manusia pada saat itu.

Daun pisang menggambarkan sebagai kehidupan gaib atau yang nyata namun tak terlihat. Keistimewaan dari pohon pisang yaitu dia tidak akan mati sebelum menghasilkan buah (Fitria, 2019). Hal ini dimaknai dengan pohon pisang yang memberikan kemakmuran.Sedangkan bambu menggambarkan sebagai penghubung antara dunia nyata dengan dunia gaib.Hal ini dikarenakan batang bambu yang sering digunakan sebagai penopang dalam kehidupan manusia.Banyak peneliti yang menyarankan bambu sebagai alternatif dalam membangun dan menopang bangunan. Salah satunya (Suriani, 2017) yang menyatakan bahwa bambu dapat diupayakan sebagai alternatif utama material ekologis yang masih banyak ditemui. Hal ini sudah kita jumpai sejak lama, banyak jembatan ataupun rumah yang menjadikan bambu sebagai tiang penyangga karena kekuatannya.

Tradisi perang obor sebagai bagian dari rangkaian kegiatan sedekah bumi memiliki dua nilai yang mendasar, yaitu nilai-nilai Ketuhanan dan nilai-nilai kebudayaan.Nilai-nilai Ketuhanan ini tercermin dari sejarah perang obor hingga dijadikannya sebagai media syi'ar Keislaman.Dalam perkembangannya, perang obor mengalami pergeseran fungsi dari pra Islam yang digunakan sebagai pengusir kekuatan roh jahat yang mendatangkan wabah penyakit hingga masa Islam sebagai ajang untuk syiar agama.Hal ini direpresentasikan dengan pedang kayu dan bedug peninggalan Sunan Kalijaga. Pedang kayu melambangkan agama yang kuat, sedangkan bedug melambangkan ajaran yang persuasif dan penuh kasih (Rosdiana \& Saefudin, 2018). Hingga saat ini, tradisi perang obor masih terus dilestarikan dengan diiringi empat pusaka. Keempat pusaka ini konon dipercaya warisan dari Sunan Kalijaga kepada Kebayan Tegalsambi, yang terdiri dari pedang Gendir Gampang Sari, pedang Podang Sari, sebuah arca, dan bedug Dobol (Admin, 2015).

Sedekah bumi merupakan bentuk ungkapan rasa syukur kepada Tuhan Yang Maha Kuasa atas segala nikmat yang telah diberikan. Tradisi sedekah bumi di beberapa daerah berbeda-beda, mulai dari yang hanya melakukan doa bersama di Balai Desa, mengadakan pagelaran wayang kulit, mengarak hasil bumi seperti padi, buah, dan sayur keliling desa, hingga larung (menghanyutkan) kepala kerbau ke laut. Di Desa Tegalsambi, sedekah bumi dilakukan dengan melakukan serangkaian kegiatan dengan puncak kegiatannya yaitu perang obor. Masyarakat percaya dengan Tuhan dan agama (Islam) dengan menjalankan kepercayaan yang dianutnya tanpa melakukan pemaksaan kepada umat agama lain.

Nilai-nilai Ketuhanan yang terkandung dalam tradisi perang obor dan sedekah bumi tentu sejalan dengan butir-butir sila pertama Pancasila, "Ketuhanan Yang Maha Esa"; (1) Bangsa Indonesia menyatakan kepercayaannya dan ketaqwaannya terhadap Tuhan Yang Maha Esa; (2) Manusia Indonesia percaya dan taqwa terhadap Tuhan Yang Maha Esa, sesuai dengan agama dan kepercayaannya masing-masing menurut dasar kemanusiaan yang adil dan beradab; (3) Mengembangkan sikap hormat menghormati dan bekerjasama antara pemeluk agamadengan penganut kepercayaan yang berbeda-beda

Paris Langkis

Vol.1 Nomor 2, Maret 2021 
terhadap Tuhan Yang Maha Esa; (4)Membina kerukunan hidup di antara sesama umat beragama dan kepercayaan terhadapTuhan Yang Maha Esa; (5) Agama dan kepercayaan terhadap Tuhan Yang Maha Esaadalah masalah yang menyangkut hubungan pribadi manusia dengan Tuhan Yang MahaEsa; (6) Mengembangkan sikap saling menghormati kebebasan menjalankan ibadahsesuai dengan agama dan kepercayaannya masing-masing; (7) Tidak memaksakansuatu agama dan kepercayaan terhadap Tuhan Yang Maha Esa kepada orang lain (Direktorat Jenderal Perencanaan Pertahanan Kemhan RI, 2014).

Perang obor jelas memberikan nilai-nilai budaya yang dapat dengan jelas diperhatikan dari setiap rangkaian kegiatannya.Perang obor merupakan puncak acara yang terdiri dari beberapa kegiatan dalam rangkaian budaya sedekah bumi. Rangkaian pelaksanaan perang obor terdiri dari pertemuan persiapan, pembuatan obor, penggantian sarung pusaka, ziarah makam, sesaji, pagelaran wayang kulit, perang obor, penyembuhan luka, dan pagelaran wayang kulit (Aristanto, 2011). Budaya-budaya lokal setempat inilah yang dijadikan sebagai media dalam berkomunikasi menyebarkan agama sebagai tuntunan hidup.(Khalil, 2016) juga menyebutkan bahwa membawa misi Islam kepada masyarakat sangat penting menggunakan budaya sebagai media komunikasi.

Pertemuan persiapan dipimpin oleh Kepala Desa Tegalsambi, hal ini dilakukan dalam rangka menyiapkan segala keperluan dalam rangkaian kegiatan perang obor.Persiapan inilah yang menjadi landasan dalam setiap kegiatan. Dalam perjuangan kemerdekaan, pertemuan ini diibaratkan sebagai pertemuan antara para pimpinan dan tokoh masyarakat yang akan mewujudkan kemerdekaan Indonesia. Pembuatan obor dimaknai sebagai persiapan senjata dalam menghadapi musuh bersama.Sunan Kalijaga diyakini meninggalkan sepotong kayu yang memiliki kekuatan untuk menjaga desa.Kepala Desa mencuci dan mengganti sarung pusaka tersebut sebagai perwujudan dalam menjaga benda bersejarah.Ziarah makam dilakukan kepada makam para leluhur Desa Tegalsambi.

Kegiatan-kegiatan tersebut merupakan cerminan bagaimana masyarakat Desa Tegalsambi mengupayakan kegiatan-kegiatannya berlandaskan jiwa patriotisme dan semangat nasionalisme yang tinggi sebagai Bangsa Indonesia. Kegiatan yang dilakukan merupakan bagian dari mengenang, menghormati, dan melanjutkan perjuangan dengan cara yang lain. Hal ini sejalan dengan pengamalan butir-butir sila kedua Pancasila, "Kemanusiaan yang adil dan beradab"; (1) Mengakui dan memperlakukan manusia sesuai denganharkat dan martabatnya sebagai makhluk Tuhan Yang Maha Esa; (2) Mengakui persamaan derajad, persamaan hak dan kewajiban asasi setiap manusia, tanpa membeda-bedakan suku, keturrunan, agama, kepercayaan, jenis kelamin, kedudukan sosial, warna kulit dan sebagainya; (3) Mengembangkan sikap saling mencintai sesama manusia; (4) Mengembangkan sikap saling tenggang rasa dan tepa selira; (5) Mengembangkan sikap tidak semena-mena terhadap orang lain; (6) Menjunjung tinggi nilai-nilai kemanusiaan; (7) Gemar melakukan kegiatan kemanusiaan; (8) Berani membela kebenaran dan keadilan; (9) Bangsa Indonesia merasa dirinya sebagai bagian dari seluruh umat manusia; (10) Mengembangkan sikap hormat menghormati dan bekerjasama dengan bangsa lain (Direktorat Jenderal Perencanaan Pertahanan Kemhan RI, 2014).

Paris Langkis

Vol.1 Nomor 2, Maret 2021 
Sedekah bumi yang merupakan bagian dari ungkapan rasa syukur juga memberikan sesaji bagi danyang penjaga desa.Sesaji yang digunakan dalam perang obor terdiri dari kepala kerbau dan sesaji pelengkap.Sesaji pelengkap terdiri dari nasi, lauk pauk, sayur urap, kelapa hijau, dan lain-lain. Sesaji tersebut akan digunakan dalam ritual doa bersama agar pelaksanaan perang obor berjalan dengan lancar (Aristanto, 2011). Pemberian sesaji ini bukan bagian dari musyrik atau menyekutukan Tuhan.Sesaji ini dimaknai sebagai ucapan terima kasih kepada Tuhan dan mengurbankan kerbau untuk mengganti masyarakat desa dari bala yang ada.

Wayang merupakan seni pertunjukan warisan budaya yang sering diartikan sebagai bayangan yang samar dan bergerak kesana kemari. Bayangan yang samar ini menggambarkan watak manusia yang sering berubah-ubah. Pagelaran wayang kulit diadakan dua kali, yaitu sebelum dan sesudah perang obor. Pagelaran wayang kulit sebelum perang obor dimaknai sebagai gerbang pembuka bahwa perang obor sesaat lagi akan dilaksanakan. Sedangkan pagelaran wayang kulit setelah perang obor dimaknai sebagai gerbang penutup.Dalam setiap pagelaran, cerita pewayangan selalu dibuka dan ditutup dengan gunungan, inilah yang dijadikan sebagai dasar pelaksanaan pagelaran wayang kulit dua kali.

Pegalaran wayang kulit ini juga merupakan bagian dari pelestarian budaya Indonesia.Sudah sangat jarang sekali kita menemukan pagelaran wayang kulit jika bukan di hari-hari spesial. Kepopuleran wayang kulit di masyarakat dikarenakan padat dengan nilai filosofis, pedagogis, historis, dan simbolis (Isnaeni, 2020). Cerita pewayangan umumnya menggambarkan kehidupan manusia sebagai pribadi, makhluk sosial, maupun makhluk Tuhan.Nilai-nilai yang terkandung dalam pewayangan yaitu bagaimana manusia menempatkan diri sebagai makhluk individu, makhluk sosial, dan makhluk Tuhan dengan berpegang teguh pada kebijaksanaan untuk menciptakan kehidupan yang harmonis, selaras, dan seimbang. Nilai-nilai ini tentu selaras dengan butir-butir sila keempat Pancasila, "Kerakyatan yang dipimpin oleh hikmat kebijaksanaan dalam permusyawaratan/perwakilan"; (1) Sebagai warga negara dan warga masyarakat, setiap manusia Indonesia mempunyai kedudukan, hak dan kewajiban yang sama; (2) Tidak boleh memaksakan kehendak kepada orang lain; (3) Mengutamakan musyawarah dalam mengambil keputusan untuk kepentingan bersama; (4) Musyawarah untuk mencapai mufakat diliputi oleh semangat kekeluargaan; (5) Menghormati dan menjunjung tinggi setiap keputusan yang dicapai sebagai hasil musyawarah; (6) Dengan i'tikad baik dan rasa tanggung jawab menerima dan melaksanakan hasil keputusan musyawarah; (7) Di dalam musyawarah diutamakan kepentingan bersama di atas kepentingan pribadi dan golongan; (8) Musyawarah dilakukan dengan akal sehat dan sesuai dengan hati nurani yang luhur; (9) Keputusan yang diambil harus dapat dipertanggungjawabkan secara moral kepada Tuhan Yang Maha Esa, menjunjung tinggi harkat dan martabat manusia, nilai-nilai kebenaran dan keadilan mengutamakan persatuan dan kesatuan demi kepentingan bersama; (10) Memberikan kepercayaan kepada wakil-wakil yang dipercayai untuk melaksanakan pemusyawaratan(Direktorat Jenderal Perencanaan Pertahanan Kemhan RI, 2014).

Perang yang disaksikan oleh ribuan warga menjadi daya tarik tersendiri, mengingat para peserta terlihat bersungguh-sungguh layaknya berperang mengahadapi

Paris Langkis

Vol.1 Nomor 2, Maret 2021 
musuh negara.Perang ini dimaknai masyarakat setempat sebagai perang melawan kejahatan dan mengusir penyakit.Nilai kearifan lokal yang tercermin dalam peristiwa ini yaitu semangat perjuangan dan gotong royong.Semangat perjuangan ini tervisualisasi dari masyarakat yang berperang melawan kejahatan dan wabah penyakit tanpa kenal rasa takut.Masyarakat senantiasa berjuang dalam memperjuangkan kesejahteraan dan kesehatan, khususnya bagi masyarakat Desa Tegalsambi.Para peserta tidak melakukan perang sendiri-sendiri, mereka saling bersatu padu dalam melawan musuh. Semangat gotong royong, tolong menolong, persatuan dan kesatuan inilah yang menjadikan para peserta saling percaya satu sama lain. Semangat inilah yang dibutuhkan Bangsa Indonesia hingga saat ini.

Semangat perjuangan sebagai nilai kearifan lokal ini selaras dengan butir-butir sila ketiga Pancasila, "Persatuan Indonesia"; (1) Mampu menempatkan persatuan, kesatuan, serta kepentingan dan keselamatan bangsa dan negara sebagai kepentingan bersama di atas kepentingan pribadi dan golongan; (2) Sanggup dan rela berkorban untuk kepentingan negara dan bangsa apabila diperlukan; (3) Mengembangkan rasa cinta kepada tanah air dan bangsa; (4) Mengembangkan rasa kebanggaan berkebangsaan dan bertanah air Indonesia; (5) Memelihara ketertiban dunia yang berdasarkan kemerdekaan, perdamaian abadi dan keadilan sosial; (6) Mengembangkan persatuan Indonesia atas dasar Bhinneka Tunggal Ika; (7) Memajukan pergaulan demi persatuan dan kesatuan bangsa(Direktorat Jenderal Perencanaan Pertahanan Kemhan RI, 2014).

Nilai kearifan lokal semangat gotong royong dan mengupayakan kesejahteraan masyarakat mencerminkan butir-butir sila kelima Pancasila, "Keadilan sosial bagi seluruh rakyat Indonesia"; (1) Mengembangkan perbuatan yang luhur, yang mencerminkan sikap dan suasana kekeluargaan dan kegotongroyongan; (2)Mengembangkan sikap adil terhadap sesama; (3) Menjaga keseimbangan antara hak dan kewajiban; (4) Menghormati hak orang lain; (5) Suka memberi pertolongan kepada orang lain agar dapat berdiri sendiri;(6) Tidak menggunakan hak milik untuk usaha-usaha yang bersifat pemerasan terhadap orang lain; (7) Tidak menggunakan hak milik untuk hal-hal yang bersifat pemborosan dan gaya hidup mewah; (8) Tidak menggunakan hak milik untuk bertentangan dengan atau merugikan kepentingan umum; (9) Suka bekerja keras; (10) Suka menghargai hasil karya orang lain yang bermanfaat bagi kemajuan dan kesejahteraan bersama; (11) Suka melakukan kegiatan dalam rangka mewujudkan kemajuan yang merata dan berkeadilan sosial(Direktorat Jenderal Perencanaan Pertahanan Kemhan RI, 2014).

Uraian diatas menunjukkan bahwa nilai-nilai kearifan lokal yang terkandung dalam tradisi perang obor merupakan cerminan dari Pancasila.45 butir pedoman penghayatan dan pengamalan Pancasila tervisualisasi secara jelas dalam tradisi perang obor di Desa Tegalsambi.Hal tersebut mengindikasikan bahwa tradisi perang obor merupakan bagian dari pengamalan semangat nasionalisme di era sekarang. Oleh karena itu, keberlangsungan tradisi ini tidak boleh luntur.Selain sebagai warisan budaya, perang obor juga sebagai media dalam mengeratkan persatuan dan kesatuan bangsa di era sekarang.

Paris Langkis

Vol.1 Nomor 2, Maret 2021 
Nasionalisme dalam sejarah perjuangan kemerdekaan Indonesia dikenal sebagai kata sakti yang mampu membangkitkan kekuatan berjuang melawan penindasan dan ketidakadilan.Para pejuang dengan gagah berani dan lantang meneriakkan "Hidup atau mati" dalam setiap pertempuran.Dewasa ini, musuh kita bukanlah kolonial ataupun penjajah.Musuh kita semakin bermacam-macam jenis dan bentuknya, mulai dari yang terlihat hingga yang tak terlihat.Kriminalitas, kemiskinan, pendidikan yang rendah, degradasi semangat nasionalisme merupakan contoh musuh kita saat ini.Dalam melawan musuh-musuh bangsa yang sudah bermutasi menjadi berbagai macam bentuk, diperlukan semangat yang baru. Semangat ini tercermin dalam semangat gotong royong dan saling percaya satu sama lain.

Budaya gotong royong sejatinya bukanlah hal yang baru dan asing.Gotong royong sudah menjadi ciri khas yang melekat pada diri masyarakat Indonesia.Dewasa ini, semangat gotong royong dalam hal apapun sudah memudar dan jarang sekali ditemukan(Oktaviyani \& Sukmayadi, 2020). Hal ini disebabkan oleh munculnya budaya individualisme di masyarakat, sehingga masyarakat mulai abai tentang pentingnya menjaga semangat gotong royong.Penguatan nilai-nilai gotong royong dapat dilihat melalui tiga aspek, yaitu mengubah persepsi masyarakat, mengupayakan budaya gotong royong, dan memvisualisasikan nilai-nilai yang terkandung di dalamnya (Oktaviyani \& Sukmayadi, 2020).

Menurut (Liliweri, 2011) terdapat komponen kebudayaan yang sangat penting, antara lain (1) pandangan hidup (kosmologi dan ontologi); (2) bahasa dan sistem simbol; (3) skema kognitif; (4) kepercayaan dan nilai; (5) konsep tentang waktu; (6) konsep tentang jarak dan ruang; (7) agama dan bentuk-bentuk ekspresi; serta (8) hubungan sosial dan jaringan komunikasi. Apabila dipandang berdasarkan teori Alo Liliweri, tradisi perang obor sudah menjadi bagian dari suatu kebudayaan yang eksistensinya sangat penting.Perang obor sebagai salah satu rangkaian sedekah bumi yang menunjukkan ungkapan syukur kepada Tuhan sudah menjadi pandangan hidup yang utuh bagi masyarakat setempat. Benda-benda bersejarah berupa pedang kayu, arca, dan bedug serta beberapa benda lain yang digunakan sebagai sesaji menjadi sebuah simbol dan bahasa dalam dimensi yang lain.

Perang obor memberikan pembelajaran bahwa mengalahkan "musuh" hanya dengan bersatu untuk membuat satu kekuatan yang mampu menangkis serangan lawan hingga menyerang lawan.Perang obor dan sedekah bumi memiliki nilai-nilai luhur dan nilai-nilai kearifan lokal yang terkandung didalamnya sebagai bagian yang tak terpisahkan dalam mengilhami kemerdekaan dan semangat patriotisme itu sendiri.Sejarah menunjukkan bahwa tradisi perang obor ini mengalami perubahan baik dari segi tujuan hingga teknis pelaksanaan.Perubahan inilahyang mengindikasikan adanya konsep ruang dan waktu dalam kehidupan. Ungkapan syukur kepada Tuhan dan doa yang dipanjatkan kepada Tuhan menunjukkan manusia sebagai makhluk Tuhan dan menggantungkan harapan serta kehidupannya di tangan Tuhan. Hubungan sosial dan komunikasi inilah yang menjadikan tradisi perang obor tersohor sehingga kehadirannya sangat ditunggutunggu.

Ritual umumnya dipahami sebagai ungkapan kepercayaan, terkait dengan berbagai peristiwa yang dianggap penting bagi kehidupan manusia.Dalam perang obor

Paris Langkis

Vol.1 Nomor 2, Maret 2021 
terkandung kosmologi dan simbol yang diekspresikan dalam bentuk tindakan dan kepercayaan dalam indentifikasi dan penafsirannya.Perilaku ritual bersifat simbolis, yang mana menunjukkan beberapa informasi mengenai situasi persoalan, tetapi tidak harus memiliki implikasi dalam hal tindakan (Dhavamony, 1995). Serangkaian kegiatan dalam upacara tradisi perang obor merupakan bagian dari iman keagamaan.Tafsiran dan makna yang dipercaya oleh masyarakat setempatlah yang mengarahkan vitalitas dari pelaksaan ritual tersebut sebagai bagian dari kebudayaan.

Persatuan dan gotong royong dalam perang obor dimaknai semangat melawan kejahatan dan menjaga desa dari berbagai ancaman seperti wabah penyakit.Hal ini menunjukkan, walaupun budaya gotong royong sudah pudar, namun keberadaan dan eksistensinya masih senantiasa melekat pada setiap sendi-sendi kehidupan.Perang obor menjadi salah satu titik balik yang menunjukkan keberadaan semangat perjuangan dan gotong royong di masyarakat Indonesia.

\section{E. KESIMPULAN}

Perang obor menjadi salah satu tradisi tahunan yang sudah dijalankan oleh masyarakat Desa Tegalsambi, Kabupaten Jepara.Tujuan diadakannya perang obor ini untuk mengusir penyakit dan menolak bala dari segala macam gangguan dan menghindarkan masyarakat setempat dari mara bahaya.Perang obor memiliki dua nilai yang mendasar, yaitu nilai Ketuhanan dan nilai kebudayaan.Nilai-nilai kearifan lokal yang terkandung didalamnya seperti kebersamaan, gotong royong, empati, kesetiakawanan, religius, dan lain-lain sejalan dengan semangat nasionalisme.Hal ini ditunjukkan dengan uraian tentang nilai kearifan lokal perang obor yang merupakan cerminan dari Pancasila sesuai dengan 45 butir pedoman penghayatan dan pengamalan Pancasila.Nilai-nilai persatuan dan gotong royong yang secara nyata ditunjukkan dalam perang obor mengindikasikan bahwa eksistensinya masih senantiasa melekat pada setiap sendi-sendi kehidupan. 


\section{DAFTAR PUSTAKA}

Admin. (2015). Sedekah Bumi dan Ritual Perang Obor Desa Tegalsambi Info Seputar Jepara. https://www.infoseputarjepara.com/2015/04/sedekah-bumi-dan-ritual-perangobor.html

Agustin, D. S. Y. (2011). Penurunan Rasa Cinta Budaya Dan Nasionalisme Generasi Muda Akibat Globalisasi. Jurnal Sosial Humaniora, 4(2), 177-185. https://doi.org/10.12962/j24433527.v4i2.632

Alfian, T. I. (1996). Nasionalisme dalam Perspektif Sejarah. Jurnal Filsafat Pancasila, 2(2).

Aristanto, Z. (2011). PERANG OBOR: Upacara Tradisi di Tegal Sambi, Tahunan, Jepara. Sabda, 6(1), 88-94.

Dhavamony, M. (1995). Fenomena Agama. Kanisius.

Direktorat Jenderal Perencanaan Pertahanan Kemhan RI. (2014). 45 butir Pedoman Penghayatan dan Pengamalan Pancasila. https://www.kemhan.go.id/renhan/2014/11/20/45-butir-pedoman-penghayatandan-pengamalan-pancasila.html

Fitria, R. (2019). Makna 5 Makanan dan Minuman yang Sering Jadi Sesajen. https://food.detik.com/info-kuliner/d-4690252/makna-5-makanan-dan-minumanyang-sering-jadi-sesajen

Harsojo. (1988). Pengantar Antropologi. Binacipta.

Isnaeni. (2020). Al-Qur'an dan Prakti Sedekah Bumi di Desa Kedungneng Kecamatan Losari Kabupaten Brebes [Universitas Islam Negeri Syarif Hidayatullah]. http://repository.uinjkt.ac.id/dspace/bitstream/123456789/51651/1/Baru Skripsi Isnaeni__11150340000122.pdf

Khalil, A. I. A. E.-F. (2016). The Islamic Perspective of Interpersonal Communication. Journal of Islamic Studies and Culture, 4(2), 22-37.

Liliweri, A. (2011). Gatra-Gatra Komunikasi Antarbudaya. Pustaka Pelajar.

Munandar, A. A. (2010). Gajah Mada: Biografi Politik (Satu Bahas). Komunitas bambu.

Oktaviyani, M., \& Sukmayadi, T. (2020). Penguatan nilai-nilai gotong royong di Kampung Potronanggan Kecamatan Banguntapan Kabupaten Bantul. Jurnal Citizenship: Media Publikasi Pendidikan Pancasila dan Kewarganegaraan, 3(2), 65-70.

Peursen, C. A. van. (1976). Strategi Kebudayaan (terj. Dick Hartoko). Gunung Mulia.

Ratri, S. D. P. (2010). Cerita Rakyat dan Upacara Tradisional Perang Obor di Desa Tegalsambi Kecamatan Tahunan Kabupaten Jepara Propinsi Jawa Tengah (Tinjuan Folklor). Universitas Sebelas Maret.

Rosdiana, A., \& Saefudin, A. (2018). Memperkuat Kearifan Lokal Islam Melalui Perang Obor. In Proceedings of Annual Conference for Muslim Scholars, April 2018, 879-888.

Paris Langkis

Vol.1 Nomor 2, Maret 2021 
Sartini, S. (2004). Menggali Kearifan Lokal Nusantara: Sebuah Kajian Filsafati. Jurnal Filsafat, 14(2), 111-120. https://doi.org/10.22146/JF.33910

Sedyawati, E. (2006). Budaya Indonesia: Kajian Arkeologi, Seni, dan Sejarah. PT Raja Grafindo.

Setyowati, A. (2019). Pentingnya Kebudayaan sebagai Pondasi Karakter Bangsa. Kompas.com. https://nasional.kompas.com/read/2019/12/24/06360051/pentingnyakebudayaan-sebagai-pondasi-karakter-bangsa?page $=$ all $\% 23$ page2

Supardan, D. (2013). Tantangan Nasionalisme Indonesia Dalam Era Globalisasi. Jurnal Ilmu Budaya dan Sosial LENTERA, 2(4), 37-72.

Suriani, E. (2017). Bambu Sebagai Alternatif Penerapan Material Ekologis: Potensi dan Tantangannya. EMARA Indonesian Journal of Architecture, 3(1).

Suryawandan, N. W., \& Danial, E. (2016). Implementasi Semangat Persatuan Pada Masyarakat Multikultural Melalui Agenda Forum Kerukunan Umat Beragama (FKUB) Kabupaten Malang. HUMANIKA, 23(1). 